\title{
SCREENING WHEAT GENOTYPES FOR DROUGHT TOLERANCE AND CO- RELATION STUDY AMONG MORPHO-PHYSIOLOGICAL TRAITS
}

\author{
Dipendra Pokharel ${ }^{1}$, Kiran Baral ${ }^{2}$, Bishnu R. Ojha ${ }^{3}$, Surya K. Ghimirey ${ }^{3}$ and Madhav P. Pandey ${ }^{3}$
}

\begin{abstract}
Wheat crop in developing world including Nepal is grown under rainfed condition and thus face moisture stress at one or more growth stages limiting grain yield. An experiment was conducted at Greenhouse to screen the 60 different genotypes of wheat including Nepalese landraces, commercial cultivars CIMMYT derived advanced lines, NWRP derived advanced lines, and three international drought tolerant check cultivars. The wheat genotypes were grown in pots (single plant) arranged in a replicated split plot design under two contrasting moisture regimes, optimum and moisture stressed. The genotypes were evaluated forwater use, water use efficiency, plant height, number of tillers and biomass production. The analysis revealed significant variance between environments and among the wheat genotypes for most of these traits. A wide range of variability was observed for water use, water use efficiency, days to anthesis, plant height, number of tillers and biomass yield in both moisture stressed and non stressed environments. Gautam showed superiority than Bhrikuti and Vijaya among Nepalese cultivar for drought adaptive physiological traits. Landrace NPGR 7504 showed high level of water use efficiency and other positive traits for drought adaptation.
\end{abstract}

Keywords: Co-relation, Drought, Morpho-physiological traits, Tolerance, Wheat genotypes

\section{INTRODUCTION}

Wheat (Triticum aestivum L.) is the most important cereal crop of the world providing staple food for 35\% of the world population (FAOSTAT, 2011). It is the major staple crop in the Eastern Gangetic Plains (EGP) of South Asia, a region comprising the plains of eastern India, southern Nepal, Bangladesh and Pakistan. This region is regarded as a low-income region with a vast number of small and marginalized farmers. The acreage under wheat cultivation in this region is over 36 million ha which is around $16 \%$ of the global wheat area and produces $15 \%$ of the global wheat (CIMMYT, 2009). Wheat ranks third important crop in Nepal with the production and productivity of $15,57,000 \mathrm{Mt}$ and $2.129 \mathrm{t} / \mathrm{ha}$, respectively (MOAC, 2010). It contributes $7.14 \%$ to agricultural gross domestic products (MOAC, 2010).

\footnotetext{
${ }^{1}$ Crop Development Training Officer, Regional Agricultural Training Center, Pokhara, Nepal. Ph: 9846043660, Email: dgogene@gmail.com

${ }^{2}$ Assistant Professor, Department of Genetics and Plant Breeding, Institute of Agriculture and Animal Science (IAAS), Rampur, Chitwan, Nepal.

${ }^{3}$ Associate Professor, Department of Genetics and Plant Breeding, Institute of Agriculture and Animal Science (IAAS), Rampur, Chitwan, Nepal.
} 
Water is becoming scarce for wheat crop in south Asia as less water recharge from rainfall (Singh, 2000). Moisture stress is one of the major abiotic factors limiting wheat production worldwide (Richards et., 2001). In a survey that covered 102 million hectares of wheat area in the developing countries (47\% global wheat area or $89 \%$ of the wheat area in developing countries) revealed moisture stress as one of the major constraints to wheat production with and estimated annual yield loss of 19 to $50 \%$ (Kosina et al., 2007). Annual wheat yield loss of up to 15\% has been reported due to drought stress in the UK (Foulkes et al., 2007).

Drought stress has been recognized as one of the major abiotic factors limiting wheat production in India (Joshi et al., 2007), Pakistan (Kisana et al., 2008) and Nepal (Bhatta et al., 2008). In Nepal, drought majorly winter drought constraints on yields have increased in importance as climate change leads to increasingly hotter and drier days (WFP, 2009). As a result, crop growth rate is reduced and yield is lowered. Despite these risks, there is a large untapped yield potential by screening drought tolerant crop genotypes of different crops in rain-fed agriculture that needs to be explored.

Nepal being the hotspot of biodiversity (Shrestha and Shrestha, 1999) encompasses the existence of four hundred and five local landraces of wheat local landraces from northwestern districts of Jumla and Humla. Genetic resources provide an invaluable gene pool for crop breeding (Reynold et al., 2007), the majority of wheat landraces in Nepal were uncharacterized for drought tolerance and their potential to improve drought adaptation is not quantified.

Information regarding character association is of paramount importance for a plant breeder to ascertain the expected response of other characters when selection is exercised to the character of interest in a breeding program and it is measured by coefficient of correlation (Dabholkar, 1992). Khaliq et al. (2008) reported positive association of flag leaf area and grain yield in bread wheat. Correspondingly, specific flag leaf area also exhibited strong positive relationship with yield, while negative association with specific leaf weight. Relative water content was found positively associated with the relative dry weight (Clarke et al.,1991). Tiwari and Rawat (1993); Sharma et al.,(1995) and Yagdi and Sozen (2009) reported that grain yield per plant in wheat was significantly and positively correlated with plant height, ear length, tillers per plant, biological yield and ears per plant. Biological yield in wheat showed positive and significant correlation with grain yield, tillers per plant, test weight and flag leaf area, while negative association with days to heading and harvest index (Munir et al., 2007). Subhani and Chowdhry (2000) found a positive relationship of grain yield with flag leaf area, plant height, spike length, grains per spike, test weight, biomass per plant and harvest index, while days to booting shows negative correlation with grain yield. 


\section{OBJECTIVES}

This study was designed to screen different genotypes of wheat in a semicontrolled experimental setup with two contrasting moisture regimes, (1) moisture stressed and (2) optimum moisture, in order to identify important drought adaptive traits and variability in these traits. The objectives of the study were to screen 60 different genotypes of wheat for drought stress tolerance and estimate the range of variability present for these traits and $t$ study the corelation among the selected morpho-physiological traits of wheat evaluated under two contrasting moisture regimes.

\section{MATERIALS AND METHODS}

This study was conducted in a Greenhouse of Institute of Agriculture and Animal Science (IAAS), Rampur, Chitwan, Nepal in 2009. In total 60 wheat genotypes were included in the study. This comprised of 24 Nepalese wheat landraces obtained from the Agricultural Botany Division, Nepal Agricultural Research Council (NARC), Khumaltar, Kathmandu; 30 advanced breeding lines from the National Wheat Research Program, NARC, Bhairahawa; three international check cultivars namely, Dharwar Dry (drought tolerant), Hartog (standard high yielding cultivar) and SeriM82 (a high yielding cultivar recommended for water limiting areas). Dharwar Dry is an Indian landrace selected by CIMMYT for dry areas, whereas, Hartog and SeriM82 are Australian cultivars. The seeds of these three wheat cultivars were kindly provided by the Queensland Department of Primary Industries and Fisheries, Leslie Research Centre, Australia. In addition to this, 3 Nepalese commercial cultivars- Gautam, Bhrikuti and Vijaya were also included in the study. The details of the wheat genotypes used in this study are given in Table 1 .

\section{DESIGN AND LAYOUT OF THE EXPERIMENT}

The experiment was laid out in split plot design with optimum moisture and moisture stressed environments as main plot factors and 60 wheat genotypes as sub-plot factors. Each set of experiment was replicated three times. Plastic bins ( $n=360$ ) of $12 \mathrm{~cm}$ diameter and $30 \mathrm{~cm}$ depth, purchased from the local market were used to raise wheat genotypes in the Greenhouse. Daily temperature and relative humidity of the green house were taken. The minimum, maximum, mean air temperature and relative humidity recorded during the water stress imposed period of the experiment is shown in the Figure 1.

Each pot was filled with $7.5 \mathrm{~kg}$ of sandy loam soil (moisture content at $75 \%$ field capacity) taken from the wheat-growing field of IAAS research farm. Three seeds of each genotype were sown in each pot in December 06 2009. Thinning was done on January 062010 and single seedling of each line was maintained in each pot. All the pots of irrigated set were watered weekly to maintain initial soil moisture content (sandy loam with $75 \%$ of field capacity), i.e., $7.5 \mathrm{~kg}$ weight throughout the experiment. For moisture stressed experiment, soil moisture content was 
maintained at $35 \%$ of field capacity (i.e., $6.5 \mathrm{~kg}$ soil weight) by withholding watering at tillering (growth stage 20, Zadok scale) until harvested at flowering stage (growth stage 60, Zadok scale). Evapo-transpiration was recorded for each pot regularly and the amount of water transpired by the plants was estimated based on six evaporation control pots randomly placed in the greenhouse.

Table 1. Details of the sixty wheat genotypes and their origin/ source.

\begin{tabular}{|c|c|c|c|c|c|c|c|}
\hline S.N. & Genotype & Type ${ }^{1}$ & Source & S.N. & Genotype & Type $^{1}$ & Source \\
\hline 1 & BL 3791 & Adv. Line & NWRP & 31 & BL 3787 & Adv. Line & NWRP \\
\hline 2 & Dharwar dry & Landrace & QDPIF/India & 32 & ABL17 & Adv. Line & NWRP \\
\hline 3 & SeriM82 & Adv. Line & QDPIF/ CIMMYT & 33 & NPGR 5610 & Landrace & Nepal \\
\hline 4 & Hartog & Cultivar & QDPIF/Australia & 34 & NPGR 5988 & Landrace & Nepal \\
\hline 5 & BL 3798 & Adv. Line & NWRP & 35 & NPGR 6001 & Landrace & Nepal \\
\hline 6 & Bhrikuti & Cultivar & NWRP/Nepal & 36 & NPGR 6573 & Landrace & Nepal \\
\hline 7 & BL 3827 & Adv. Line & NWRP & 37 & NPGR 6612 & Landrace & Nepal \\
\hline 8 & BL 3845 & Adv. Line & NWRP & 38 & NPGR 6696 & Landrace & Nepal \\
\hline 9 & Gautam & Cultivar & NWRP/Nepal & 39 & NPGR 7439 & Landrace & Nepal \\
\hline 10 & BL 3899 & Adv. Line & NWRP & 40 & NPGR 7487 & Landrace & Nepal \\
\hline 11 & BL 2800 & Adv. Line & NWRP & 41 & NPGR 7504 & Landrace & Nepal \\
\hline 12 & BL 3924 & Adv. Line & NWRP & 42 & NPGR 7782 & Landrace & Nepal \\
\hline 13 & BL 3940 & Adv. Line & NWRP & 43 & NPGR 7789 & Landrace & Nepal \\
\hline 14 & ABL1 & Adv. Line & NWRP & 44 & NPGR 8228 & Landrace & Nepal \\
\hline 15 & $\mathrm{ABL} 2$ & Adv. Line & NWRP & 45 & NPGR 8232 & Landrace & Nepal \\
\hline 16 & $\mathrm{ABL} 3$ & Adv. Line & NWRP & 46 & NPGR 8233 & Landrace & Nepal \\
\hline 17 & ABL4 & Adv. Line & NWRP & 47 & NPGR 8748 & Landrace & Nepal \\
\hline 18 & ABL5 & Adv. Line & NWRP & 48 & NPGR 8749 & Landrace & Nepal \\
\hline 19 & ABL6 & Adv. Line & NWRP & 49 & NPGR 8752 & Landrace & Nepal \\
\hline 20 & ABL7 & Adv. Line & NWRP & 50 & NPGR 8753 & Landrace & Nepal \\
\hline 21 & ABL8 & Adv. Line & NWRP & 51 & NPGR 8762 & Landrace & Nepal \\
\hline 22 & ABL9 & Adv. Line & NWRP & 52 & NPGR 8903 & Landrace & Nepal \\
\hline 23 & ABL10 & Adv. Line & NWRP & 53 & NPGR 8904 & Landrace & Nepal \\
\hline 24 & ABL11 & Adv. Line & NWRP & 54 & NPGR 8911 & Landrace & Nepal \\
\hline 25 & ABL12 & Adv. Line & NWRP & 55 & NPGR 9447 & Landrace & Nepal \\
\hline 26 & ABL13 & Adv. Line & NWRP & 56 & NPGR 10548 & Landrace & Nepal \\
\hline 27 & ABL14 & Adv. Line & NWRP & 57 & NL 1042 & Adv. Line & NWRP \\
\hline 28 & ABL15 & Adv. Line & NWRP & 58 & BL 3625 & Adv. Line & NWRP \\
\hline 29 & ABL16 & Adv. Line & NWRP & 59 & Vijaya & Cultivar & NWRP/Nepal \\
\hline 30 & BL3561 & Adv. Line & NWRP & 60 & BL3555 & Adv. Line & NWRP \\
\hline
\end{tabular}

${ }^{1}$ Adv. lines=Advanced breeding lines. NWRP=National Wheat Research Program, QDPIF=Queensland Department of Primary Industries and Fisheries (Australia). 


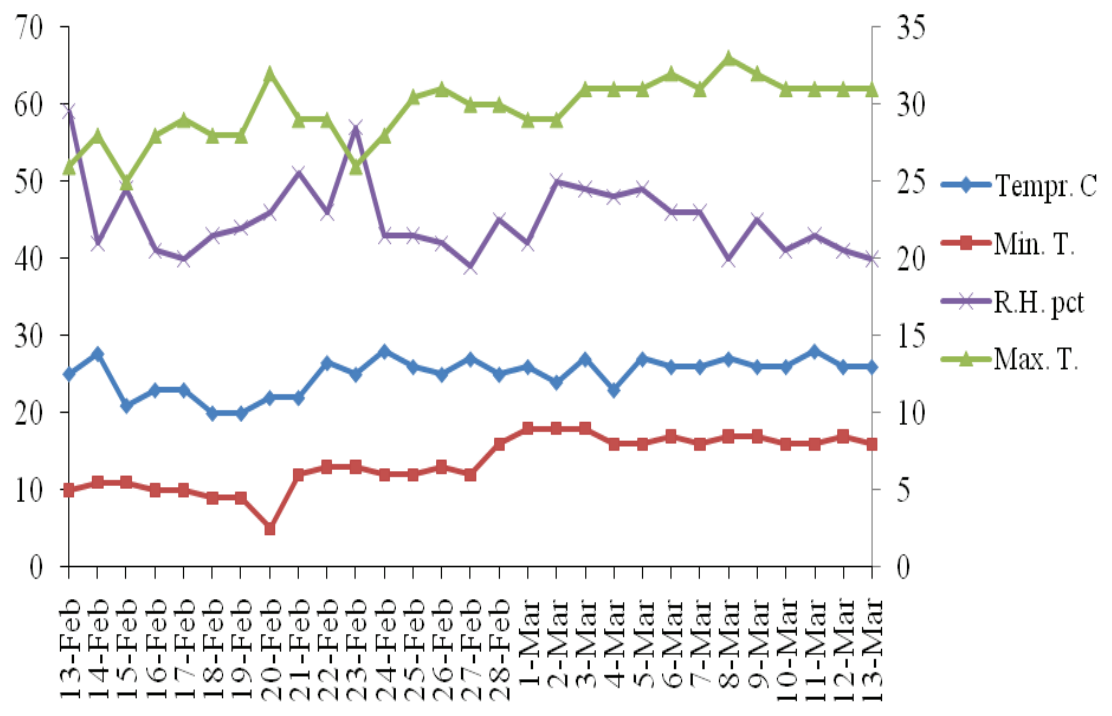

Figure 1. Minimum, maximum and mean temperature and relative humidity of the green house during the research 2009.

\section{DATA RECORDING AND ANALYSIS}

The observations were taken for the following morpho-physiological characteristics.

\section{Water Use and Water Use Efficiency}

Water use by different wheat lines were estimated by weighing the pot on a weekly interval. In addition, for water use efficiency the biomass weight from each plant was divided by the water use per plant to get the water use efficiency.

Water Use Efficiency $=$ Biomass production /Water use

\section{Number of Tillers per Plant}

The number of effective tillers per plant was determined at the flowering stage of wheat (growth stage 60, Zadok scale).

\section{Plant Height}

The plant height was measured from the soil surface in $\mathrm{cm}$ up to the height of the top of the uppermost spikelet at the time of harvesting.

\section{Phenological Periods}

Days to booting, heading and anthesis were recorded.

\section{Biomass Production per Plant}

Biomass yield per plant was determined as gram per plant. Above ground biomass yield was taken at the flowering stage for both moisture stressed and irrigated condition. 


\section{STATISTICAL ANALYSIS}

Data were processed in the Microsoft Office Excel 2007. Analysis of variance and means were computed with GENSTAT software (Discovery Edition package) developed by VSN International. Paired t-test (was used to analyze the difference between the moisture stressed and not stressed condition) and correlation analysis was done with SPSS 16.

\section{RESULTS AND DISCUSSIONS}

\section{PHENOLOGICAL PARAMETERS}

The days to booting, days to heading and days to anthesis of wheat evaluated under the optimum moisture regime were 73,81 and 83 respectively whereas it was 69,77 and 80 under the moisture stressed condition. Analysis of variance reveled that there is a highly significant differences among the genotypes used in this experiment (Table 2). The phenological parameters in the two contrasting moisture regimes were statistically highly significant (Table 3 ).

Table 2. Mean squares of ANOVA of morpho-physiological traits as influenced by moisture regime and genotypes at Greenhouse, Rampur, Chitwan 2009.

\begin{tabular}{|c|c|c|c|c|c|c|c|c|}
\hline Source & Df & $\begin{array}{l}\text { Days to } \\
\text { booting }\end{array}$ & $\begin{array}{l}\text { Days to } \\
\text { anthesis }\end{array}$ & $\begin{array}{l}\text { Water } \\
\text { use }\end{array}$ & $\begin{array}{l}\text { Biomass } \\
\text { productio } \\
\mathrm{n}\end{array}$ & WUE & $\begin{array}{l}\text { Plant } \\
\text { height }\end{array}$ & $\begin{array}{l}\text { No. of } \\
\text { tillers }\end{array}$ \\
\hline Replication & 2 & 3.17 & 17.72 & 0.1287 & 0.727 & 9.493 & 1161.21 & 1.433 \\
\hline $\begin{array}{l}\text { Moisture } \\
\text { regime (A) }\end{array}$ & 1 & 1472.18 & 1625.62 & $108.1^{\text {** }}$ & $3009.67^{* *}$ & $306.02^{* *}$ & 16889.12 & $41.344^{*}$ \\
\hline Error (a) & 2 & 8.25 & 16.97 & 0.1061 & 12.326 & 3.361 & 795.007 & 2.211 \\
\hline $\begin{array}{l}\text { Genotypes } \\
\text { (B) }\end{array}$ & 59 & $65.96^{* *}$ & $46.95^{* *}$ & $0.1156^{*}$ & $21.573^{* *}$ & $17.078^{* *}$ & $1056.06^{* *}$ & $1.459^{* *}$ \\
\hline$A \times B$ & 59 & 14.41 & 3.44 & $0.111^{\text {** }}$ & $5.99^{* *}$ & $12.498^{* *}$ & 1140.11 & 0.841 \\
\hline Error (b) & $\begin{array}{l}23 \\
6\end{array}$ & 17.39 & 16.17 & 0.0617 & 3.588 & 3.755 & 1026.87 & 0.926 \\
\hline
\end{tabular}

*, ** Significant at 0.05 and 0.01 probability levels, respectively. Df: degree of freedon; WUE: Water use efficiency

Olivares-Villegas et al. (2007) found reduction in days to booting, heading and anthesis in wheat crop by $10 \%$ in moisture stress condition. Reduced growth duration is associated with reduced leaf number (Blum, 2005). Early flowering has been associated with drought escape in spring wheat in environments subjected to severe early season drought stress. 
Table 3. Significance test of environment means for the phenological parameters in 60 wheat genotypes.

\begin{tabular}{llll}
\hline Treatment & Days to booting & Days to heading & Days to anthesis \\
\hline Irrigated mean & 73.1830 & 81.3055 & 83.5556 \\
SEM (irrigated condition) & 0.46018 & 0.38484 & 0.38316 \\
Drought mean & 69.1386 & 77.055 & 80.1611 \\
SEM (drought condition) & 0.48449 & 0.36309 & 0.32845 \\
t- value & $10.108^{* *}$ & $21.743^{* *}$ & $15.884^{* *}$ \\
\hline
\end{tabular}

*, ** Significant at 0.05 and 0.01 probability levels, respectively. SEM = Standard error of mean

\section{WATER USE}

The amount of water used (WU) by different genotypes of wheat in optimum moisture environments ranged from 1266 to $2390 \mathrm{ml}$, whereas in moisture stressed environment, WU ranged from 606 to $880 \mathrm{ml}$ which was shown in the Figure 2. The genotype vs. moisture regime interaction for WU was highly significant (Table 2) indicating water use pattern of genotypes changed with water availability. This is in conformity with result of Dodig et al., (2008). BL2800, Gautam, Hartog, and Dharwar dry had higher WU values in non stressed environment in contrast to SeriM82, NPGR6696, Vijaya and Bhrikuti which used minimum water during the test period.

\section{BIOMASS PRODUCTION}

he amount of biomass produced by different genotypes of wheat was found highly significant (Table 2) and also for optimum and moisture stressed conditions (Table 4). The average biomass weight was $12.3543 \mathrm{~g}$ in optimum moisture condition whereas it was $6.5715 \mathrm{~g}$ in stressed condition. The biomass production ranged from 3.52 to $17.82 \mathrm{~g}$ in non-stressed environment and 3.26 to $7.43 \mathrm{~g}$ in moisture stressed environment. The mean biomass produced by the wheat genotypes in moisture stressed environment was significantly lower than that in the non stressed environment. Reduction in biomass due to moisture stress had been reported by Zhu et al. (2008). Under optimum moisture, NPGR 8762, ABL 17 and Gautam had the highest biomass. Similarly, in moisture stressed condition, NPGR 8753, NL 1042 and Gautam had the highest biomass. The drought tolerant Indian landrace Dharwar dry and Nepalese cv. Vijaya had average biomass, whereas, NPGR 8753, ABL12 and NPGR 8228 had minimum biomass production. 


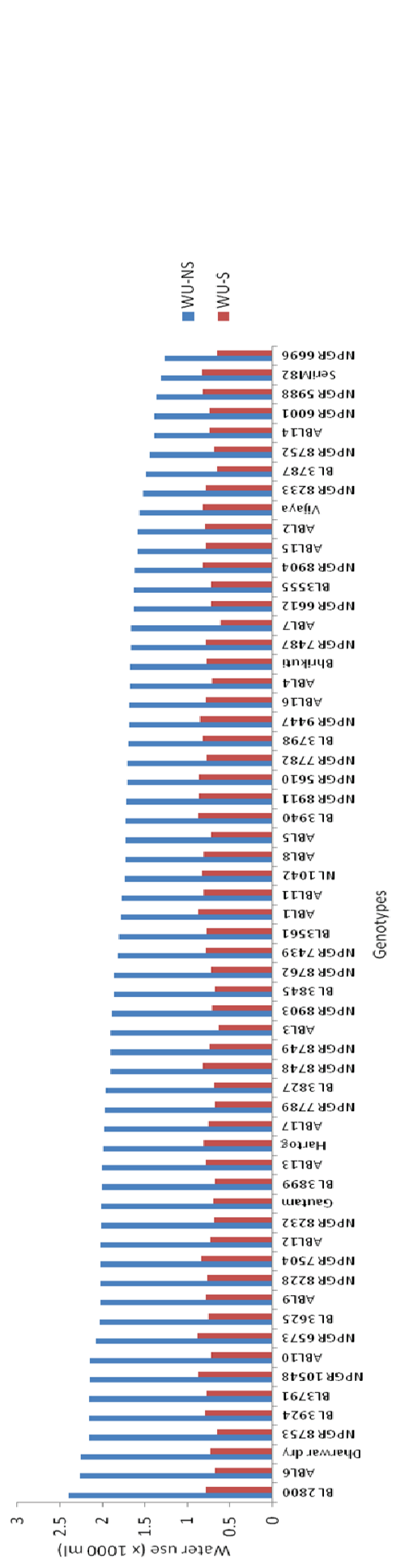

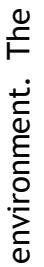

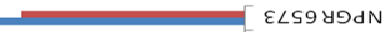
mamiminum $8228 \mathrm{y} 9 \mathrm{dN}$ แมnแ"

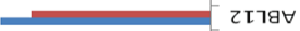

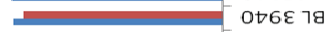
(ก)

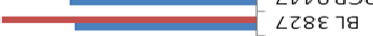

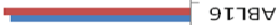

แmm- ".

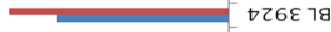

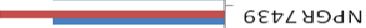

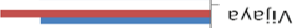

"

โละ" $6 \angle \varepsilon 79$

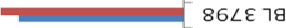

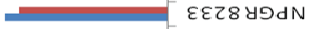

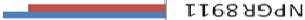

oนา

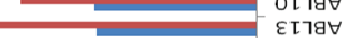

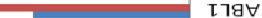

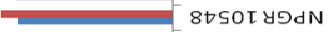
แm

등

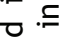
mminm вом.

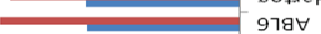

มะแ

ำ $529 \varepsilon 79$

mumun

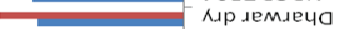

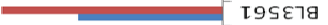

mum

HAM

ญั

근 ํํㅁ

ญั 잉

an on

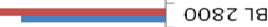

프.

패ำ

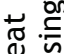

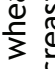

융

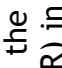

츠오

है

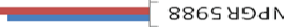

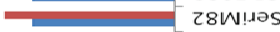

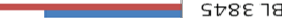

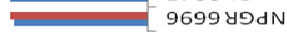

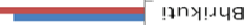

"

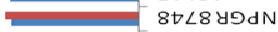

"मालm

mum minmintmin L009 y9dN

แม"

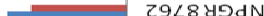

믈

告

กิ $\frac{0}{3}$

ن'

\岁

$\varepsilon$

हั

능

둰

민

ฆิ 옫

กั

ญ. 巳

을. 들

वे

으

旁

$\stackrel{\square}{ \pm}$

¿

उัष

ำ

ह

है ฮ

凹ั 음

๘

$\stackrel{ \pm}{3} \frac{1}{\pi}$

>

ก ญ

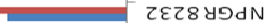

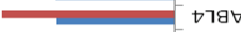

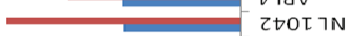

mm-

แมัตाกm

manamun

men+minm $\angle 8 \mathrm{~b} \angle \mathrm{y} 9 \mathrm{dN}$

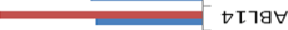

แ"

는 궁

ํํำ

ํํำ वे

앙 윰윰 욱 응

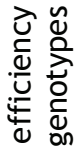

$\stackrel{凶}{\Xi}$

$\bar{d}$

$\pi$

$\frac{\pi}{\frac{1}{2}}$

ले

닌 은

跬

计 
Table 4. Significance test of environment means for the morpho-physiological traits in 60 wheat genotypes.

\begin{tabular}{lllllll}
\hline Treatments & $\begin{array}{l}\text { Water use } \\
(\mathrm{l})\end{array}$ & $\begin{array}{l}\text { Biomass production } \\
(\mathrm{g})\end{array}$ & $\begin{array}{l}\text { Water use } \\
\text { efficiency }(\mathrm{g} / \mathrm{l})\end{array}$ & $\begin{array}{l}\text { RWC } \\
(\%)\end{array}$ & $\begin{array}{l}\text { Plant height } \\
(\mathrm{cm})\end{array}$ & $\begin{array}{l}\text { Number } \\
\text { of tillers }\end{array}$ \\
\hline Irrigated Mean & 1.8565 & 12.3543 & 5.5792 & 73.0629 & 64.1544 & 2.3889 \\
SEM (irrigated condition) & 0.03437 & 0.45101 & 0.23677 & 1.14634 & 0.85158 & 0.9005 \\
Drought Mean & 0.7606 & 6.5715 & 7.2153 & 68.4713 & 57.0961 & 1.7111 \\
SEM (drought condition) & 0.00887 & 0.18938 & 0.19906 & 0.85227 & 0.66660 & 0.06837 \\
t- value & $31.187^{* *}$ & $11.832^{* *}$ & $-6.318^{* *}$ & $2.957^{*}$ & $6.911^{* *}$ & $7.009^{* *}$ \\
\hline
\end{tabular}

*, ** Significant at 0.05 and 0.01 probability levels, respectively.

\section{WATER USE EFFICIENCY}

The water use efficiency (WUE), estimated as total water $(\mathrm{ml})$ transpired per unit dry matter produced (g) varied from 248.12 to 85.83 , and 239.20 to 88.67 in optimum and moisture stressed environments, respectively (Figure 3). The expression of WUE was more pronounced in moisture stressed environment. Similar results with improved WUE of winter wheat cultivars grown with limited irrigation has been reported by Zhang et al. (1998) andPoormohammadKiani et al. (2007) in sunflower. In the present study, the most water use efficient wheat genotypes were NPGR 7789, NPGR 6001, ABL7 and ABL3. The popular cv. Gautam was found water use efficient, whereas Bhrikuti, SeriM82 and Dharwar dry were found moderately efficient. The Australian cultivar Hartog, NPGR 6573 and Nepalese cV. Vijaya were characterized poor in WUE. It is worthwhile to mention that ABL3, NL1042 and Bhrikuti were highly water use efficient in moisture stressed condition, however, showed a high level of genotype $x$ environment interaction for WUE. Manschadi et al. (2007) characterized the CIMMYT line SeriM82 and Dharwar dry as drought tolerant and Hartog as a drought sensitive in Australia. The WUE estimated for these genotypes in this experiment also hinted for a similar pattern of drought adaptation (Figure 3).

\section{PLANT HEIGHT}

The plant height of 60 wheat genotypes was found highly significant as shown by the analysis of variance (Table 2) and was also highly significant for optimum moisture and stressed conditions as shown by paired t-test (Table 4). The average value of plant height in non stressed condition was $64.15 \mathrm{~cm}$ whereas it was 57.09 $\mathrm{cm}$ in drought condition. All the genotypes were found taller in non stressed condition. Genotypes namely Gautam, Hartog and Vijaya were found taller; Bhrikuti was average in height; Dhawar dry and SeriM82 were shorter in height. Olivares-Villegas et al. (2007) found large difference in the plant height in response to the reduced soil water availability and the range in height reduction under drought condition varied from 10 to 53\%, a reduction paralleled by a yield decrease. 
Drought had a pronounced effect on number of tillers per plant. The number of tillers for the 60 wheat genotypes was found highly significant (Table 2) and also between optimum and moisture stressed condition as shown by paired t-test (Table 3). The average number of tillers in irrigated condition was 2.38 whereas 1.71 in stressed condition.Early water stress in barley was found to damage the number of tillers which strongly reduced yield potential (Sahnoune et al., 2004). Genotypes, SeriM82, and Vijaya had less number of tillers, Gautam average and Bhrikuti, Hartog and Dhawardry has larger number of tillers for both the moisture regimes. However, there was a reduction of tillers by $13 \%$ on an average under moisture stressed condition.

\section{CORRELATION STUDY}

Pearson's correlation coefficients among the selected physiological traits under moisture stressed and non stressed condition are presented in Table 5 . In case of moisture non stressed condition, water use was positively correlated and highly significant with relative water content (RWC) (0.392), flag leaf area (0.273), plant height $(0.455)$, leaves number $(0.335)$, flag leaf length $(0.442)$ and tiller number (0.413). However, water use was negatively correlated with days to anthesis ($0.018)$ and highly significant negative correlation water use efficiency $(-0.381)$.

Biomass production was found to be highly significantly positive correlation with water use efficiency $(0.607)$ and negative correlation with RWC. Days to booting were highly significant and positively correlated with flag leaf area (0.377). Whereas, days to heading and anthesis had highly significant and positive correlation with leaves number. Days to anthesis were found to be positively related and highly significant with days to heading $(0.676)$ and days to booting $(0.674)$. Days to anthesis was found to be significant and positively correlated with the number of tillers $(0.296)$.

In case of moisture stressed condition, water use was positively correlated with RWC, days to booting and days to anthesis. However, it was highly significant and negatively correlated with WUE $(-0.518)$ and negative correlation with days to heading and biomass production. Water use is highly significant and positively correlated with flag leaf area $(0.505)$, plant height $(0.523)$, leaves number $(0.354)$ and positively significant correlation with flag leaf length $(0.279)$ and number of tillers $(0.262)$. Biomass production was highly significant and positively correlated with WUE (0.578). WUE is highly significant and negatively correlated with flag leaf area (-0.364) and plant height (-0.354). Flag leaf area was highly significant and positively correlated with flag leaf length $(0.760)$. Leaf number was highly significant and positively correlated with days to booting $(0.367)$ and number of tillers (0.893), whereas significant and positive correlation with days to heading and anthesis. Similar findings were also reported by Munir et al., (2007). 
Table No 5. Correlation coefficients among morpho-physiological traits based on 60 wheat genotypes evaluated for drought tolerance in Rampur, Chitwan.

\begin{tabular}{|c|c|c|c|c|c|c|c|c|c|c|c|}
\hline & WUS & BMS & WUES & RWC S & FLAS & PHTS & LFNOS & FLLS & Bootday & S Headday & Anthday S \\
\hline & WUNS & BMNS & WUE NS & RWC NS & FLANS & PHT NS & LFNONS & FLL NS & Bootday & N Headday & V! Anthday NS \\
\hline BMS & -0.198 & & & & & & & & & & \\
\hline BMNS & 0.133 & & & & & & & & & & \\
\hline WUE S & $-0.518^{* *}$ & 0.578 & & & & & & & & & \\
\hline WUE NS & $-0.381^{* *}$ & " 0.607 & & & & & & & & & \\
\hline RWC S & 0.039 & 0.054 & 0.250 & & & & & & & & \\
\hline RWC NS & $0.392^{* \prime}$ & -0.78 & -0.219 & & & & & & & & \\
\hline FLAS & $0.505^{* *}$ & -0.209 & $-0.364^{* *}$ & -0.247 & & & & & & & \\
\hline FLANS & $0.273^{* \prime \prime}$ & 0.212 & 0.009 & 0.113 & & & & & & & \\
\hline PHTS & $0.523^{* *}$ & 0.023 & $-0.354^{*}$ & -0.062 & $0.289^{*}$ & & & & & & \\
\hline PHT NS & $0.455^{* \prime}$ & 0.119 & -0.119 & 0.143 & 0.182 & & & & & & \\
\hline LFNOS & $0.354^{* \prime \prime}$ & -0.093 & 0.035 & 0.166 & 0.016 & 0.201 & & & & & \\
\hline LFNO NS & $0.355^{* *}$ & 0.118 & -0.065 & 0.117 & 0.130 & 0.184 & & & & & \\
\hline FLLS & $0.279^{*}$ & -0.129 & -0.161 & $-0.312^{*}$ & $0.760^{*}$ & 0.199 & 0.070 & & & & \\
\hline FLL NS & $0.442^{*}$ & 0.167 & -0.087 & 0.119 & $0.707^{\prime \prime}$ & $0.342^{*}$ & 0.187 & & & & \\
\hline Bootday S & 0.077 & 0.027 & 0.139 & 0.097 & 0.099 & 0.175 & $0.367^{\prime \prime}$ & 0.142 & & & \\
\hline Bootday NS & 0.93 & -0.24 & 0.002 & 0.094 & -0.052 & $0.377^{*}$ & 0.210 & 0.053 & & & \\
\hline Headday S & -0.035 & -0.063 & 0.103 & 0.003 & 0.180 & -0.030 & $0.308^{*}$ & 0.221 & $0.513^{* *}$ & & \\
\hline Headday NS & 0.018 & -0.44 & 0.043 & 0.098 & -0.014 & 0.245 & $0.349^{* \prime}$ & 0.132 & $0.676^{\prime \prime}$ & & \\
\hline Anthday S & 0.041 & -0.019 & 0.027 & 0.037 & 0.197 & 0.149 & $0.310^{*}$ & 0.188 & $0.589^{* \prime}$ & $0.905^{* *}$ & \\
\hline Anthday NS & 0.018 & -0.034 & 0.013 & 0.070 & 0.028 & 0.240 & $0.369^{\circ *}$ & 0.099 & $0.674^{\prime \prime}$ & $0.933^{*+*}$ & \\
\hline tillemoS & $0.262^{*}$ & -0.175 & 0.023 & 0.177 & -0.019 & 0.166 & $0.893^{* *}$ & 0.071 & 0.250 & 0.182 & 0.160 \\
\hline tillemo NS & $0.413^{*+*}$ & 0.144 & -0.075 & 0.111 & -0.076 & $0.263^{*}$ & $0.662^{* *+}$ & 0.100 & $0.295^{\circ}$ & $0.322^{*}$ & $0.296^{*}$ \\
\hline
\end{tabular}

*, ** Significant at 0.05 and 0.01 probability levels, respectively. (NS: non stressed condition and S: moisture stressed condition). WU: Water use; BM: Biomass weight; WUE: Water use efficiency; RWC: Relative water content; FLA: Flag leaf area, PHT: Plant height; LFNO: Leaf numbers; FL: Flag leaf length; Bootday: Booting days; Headday: Heading days; Anthday: Anthesis days; tillemo: Tiller number.

Days to booting were highly significant and positively correlated with days to heading $(0.513)$ and days to anthesis $(0.589)$. Days to heading were highly significant and positively correlated with anthesis days (0.905). Tillers per plant were positively correlated with almost all the traits in both the crosses but negatively associated with days to heading. The interrelationship between these traits showed that they are under the control of certain common genes, which can be exploited as selection criteria in breeding programs. The positive selections for one trait would also improve the other coorelated traits. This study suggested that drought tolerance showed genotypic correlations, which could lead to predictable correlated responses that can be usefully exploited for selection of drought tolerant of wheat from the breeding programs. 


\section{CONCLUSIONS}

Water use, water use efficiency, biomass yield and flag leaf relative water content are the important drought tolerance traits in wheat (Richards et al., 2002; Rampino et al., 2006). This study revealed a wide range of variability for these traits in Nepalese wheat germplasm, particularly, in landraces and advanced breeding lines. This information can be utilized for wheat improvement for drought stressed environments. Among Nepalese cultivars, Gautam was found superior; Bhrikuti was found average in terms of drought adaptability, whereas Vijay was characterized as drought sensitive. A number of landraces and advanced breeding lines possessed drought tolerance attributes. Landrace NPGR 7504 is a perspective source of favorable alleles for drought adaptation breeding. As a matter of fact that the present study was based on single plant performance and did not include a full crop cycle as well as grain yield, results are indicative and further experimentation is required to verify the findings.

\section{REFERENCES}

Blum, A., 2005. Drought resistance, water-use efficiency, and yield potential- are they compatible, dissonant, or mutually exclusive? Australian Journal of Agricultural Research, 56: 1159-1168.

CIMMYT, 2009. CIMMYT Homepage; URL: Www.cimmyt.org

Clarke, J.M., R.A. Richards, and A. G. Condon, 1991. Effect of drought on residual transpiration and its relationship with water use of wheat. Canadian Journal of Plant Sciences, 71:695-702.

Dabholkar, A. R. 1992. Elements of Biometrical Genetics. Concept Publication Camp., New Delhi, India.

Dodig, D., M. Zoric, D. Knezevic, S. R. King and G. Surlan-Momirovic, 2008. Genotype x environment interaction for wheat yield in different drought stress conditions and agronomic traits suitable for selection. Australian Journal of Agricultural Research, 59: 536-545.

FAOSTAT, 2011. FAOSTAT Homepage; URL : faostat.fao.org

Khaliq,I., A. Irshad, and M. Ahsan, 2008. Awns and flag leaf contribution towards grain yield in spring wheat (Triticum aestivum L.). Cereal Research Communication, 36:65-76.

Manschadi, A.M., G.L. Hammer, J.T. Christopher and P. deVoil, 2007. Genotypic variation in seedling root architectural traits and implications for drought adaptation in wheat (Triticum aestivum L.). Plant and Soil, 303: 115-129.

MOAC, 2010. Statistical information on Nepalese agriculture. Nepal Government, MOAC, Agri-Business Promotion and Statistics Division, Singh Durbar, Kathmandu, Nepal.

Munir, M., M. A. Chowdhry, and T. A. Malik, 2007. Correlation studies among yield and its components in bread wheat under drought conditions. International Journal of Agriculture and Biology, 9(2): 287-290.

Olivares-Villegas, J. J., M. P. Reynolds, and G. K. McDonald, 2007. Drought-adaptive attributes in the Seri/Babax hexaploid wheat population. Functional Plant Biology, 34: 189-203.

Poormohammad Kiani, S., P. Grieu, P. Maury, T. Hewezi, L. Gentzbittel and A. Sarrafi, 2007. Genetic variability for physiological traits under drought conditions and 
differential expression of water stress-associated genes in sunflower (Helianthus annuus L.). Theoretical and Applied Genetics, 114 (2):193-207.

Rampino, P., S. Pataleo, C. Gerardi, G. Mita and C. Perrotta, 2006. Drought stress response in wheat: physiological and molecular analysis of resistant and sensitive genotypes. Plant Cell Environment, 29: 2143-2152.

Reynolds, M. P., A. Mujeeb-Kazi, and M. Sawkins, 2005. Prospects for utilizing plantadaptive mechanisms to improve wheat and other crops in drought and salinity-prone environments. Annals of Applied Biology, 146: 239-259.

Reynolds, M.P., C. Saint Piere, Abu S. I. Saad, M. Vargas and G. Condon, 2007. Evaluating potential genetic gains in wheat associated with stress-adaptive traits expression in elite genetic resources under drought and heat stress, Crop Science, 47(S3): S172S189.

Richards, R. A., G. J. Rebetzke, A. G. Condon, A. F. Herwaarden, 2002. Breeding opportunities for increasing the efficiency of water use and crop yield in temperate cereals. Crop Science, 42:111-121.

Sahnoune, M., A. Adda, S. Soualem, M. K. Harch, and O. Merah, 2004. Early water-deficit effects on seminal roots morphology in barley. Agronomy, 327: 389-398.

Sharma, D. J., R. K. Yadav, and R. K. Sharma, 1995. Genetic variability and association for some yield components in winterxspring nursery of wheat. Advances of Plant Sciences in India. 8:95-99.

Shrestha, G. L., and B. Shrestha, 1999. An overview of wild relatives of cultivated plants in Nepal. In: G. L. Shrestha and B. Shrestha (eds.) Proceedings of National Conference on wild relatives of cultivated plants in Nepal. Green Energy Mission, Nepal. pp 19-23.

Singh, R. B. 2000. Environmental consequences of agricultural development: a case study from the green revolution state of Haryana. Agriculture, Ecosystem and Environment, 82:97-103.

Subhani, G. M., and M. A. Chowdhry, 2000. Correlation and path coefficient analysis in bread wheat under drought stress and normal conditions. Pakistan Journal of Biological Sciences. 3:72-77.

WFP, 2009. Food Security Bulletin-23. May 2009. Nepal Food security Monitoring system of WFP, Nepal. 6 p.

Zhang, J., X. Suib, B. Lib, B. Sub, J. Lib and D. Zhoub, 1998. An improved water-use efficiency for winter wheat grown under reduced irrigation. Field Crops Research, 59 (2): 91-98.

Zhu, L., Z.S. Liang, X. Xu, S.H. Li, J.H. Jing, and P. Monneveux, 2008. Relationships between carbon isotope discrimination and leaf morphophysiological traits in springplanted spring wheat under drought and salinity stress in Northern China. Australian Journal of Agricultural Research, 59:941-949. 